J. Perinat. Med. 16 (1988) 289

\title{
Early pregnancy disorders: Expert knowledge based consultation
}

\author{
Jacek Ruszkowski \\ Department of Biophysics and Biomathematics, Medical Center of Postgraduate \\ Education, Warsaw, Poland
}

\section{Introduction}

In recent years increasing attention is being paid to methods of assisting medical reasoning that are based on computer-assisted consultation either for clinical use or medical under- and postgraduate training. This study presents part of a research project concerned with knowledge-based consultation in a gynecological primary health service to assist doctors who might not be highly experienced, such as junior gynecologists or general practitioners working in small centers, rural areas, developing countries, etc. [8]. The need for such a facility directed at such a group of doctors may differ considerably depending on their professional skills, their experience, local diagnostic equipment etc., so that the question: "what kind of assistance the user might be expected to require?" must be carefully answered [10].

The problem of any early pregnancy disorder (EPD) must always be seen as an emergency as its prompt detection may prevent complications including those that are life-threatening. Although imminent abortion or ectopic pregnancy are usually diagnosed, their differentiation and their confusion with other possible diagnoses may result in serious difficulties even for doctors who are experienced [1].

The system presented in this paper assists in:

- differentiation within a given group of diagnostic possibilities by ranking them in an order dependent upon clinical and laboratory findings,

- selection of those diagnostic steps found to be most effective in differentiating between the various possible diagnoses.

\section{Curriculum vitae}

DR. JACEK RUSZKowsKI was born in 1946 in Poland. He studied computer science and medicine and received the M.Sc. from the faculty of Electronics and Computer Science, Technical Unviersity of Warsaw and the Ph.D. from the Medical Faculty, Medical Academy in Warsaw. Since 1974 he has

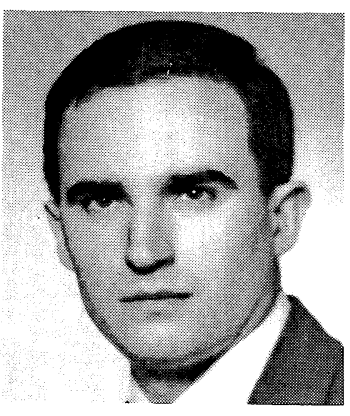
been the head of the Medical Computer Laboratory of the Medical Center of Postgraduate Education in Warsaw, where he also currently works as an adjunct professor teaching the foundations of medical computer science. His ongoing research interest is in the field of applying methods of artificial intelligence to basic problems of gynecology and obstetrics.

The principles of expert knowledge acquisition and the processing applied varies considerably from those classical rule-based methods [9] usually used for this purpose. Preliminary results of this work have already been published $[4,6,9]$.

\section{Material and methods}

Two basic questions need to be satisfied in order to fulfil the objectives proposed in this work:

- the method of the suitable consultation procedure and 
- the proper method by which the medical knowledge will be acquired and whether the means of doing so are sufficiently comprehensive and reliable.

Both these tasks should be solved within the reality of the clinical setting and should also comply with current medical practice.

A two-phased consultation procedure is proposed. As a first step the following question should be answered: "To what extent should these disorders of early pregnancy be suspected?". Until this is done, the differentiation of causes of particular EPDs cannot be carried out. In a primary health care unit, it is reasonable that special stress should be laid upon this initial step of the diagnostic procedure. The further steps aiming at differentiation between EPDs usually need procedures available in hospital only.

In relation to the course of the consultation we assumed that the diagnostic procedure would be a stepwise process with accompanying explanations where the doctor who has the diagnostic problem in mind proceeds to confirm some of the diagnostic hypotheses and to consider others as being of minor importance. In this reasoning the doctor compares possible hypothesised diagnoses (or certain groups of them) to one another, rather than trying to evaluate them according to an objective scale. Finally, with all these comparisons, he puts in rank order the set of diagnostic hypotheses he has considered with the intention of selecting one of them as the most likely, by using the minimum possible diagnostic steps. During the process of the above assumptions two interlacing phases may be distinguished:

1. The formation of the working hypotheses which is done by a relational assessment and choice of the possible reasons for the patient's complaints (explanation of the diagnostic problem), and

2. Subsequent choice of the diagnostic steps most suitable for differentiation within the set of working hypotheses formed.

Even though this scheme might be seen as a certain simplification of actual clinical management, it is accepted that this pattern is used in most clinical situations encountered by doctors.

The form of outputs of the consultation system in this work has been related to the principles of medical reasoning previously assumed; both the working hypotheses as well as the diagnostic steps proposed are to be suggested by means of ordered relations within the sets respectively of diagnostic hypotheses and of the diagnostic steps considered.

Approaching diagnosis as an explanatory process other conditions than EPD must also be considered as conceivable explanations of the symptoms mentioned. The following group of diagnostic possibilities - aetiological factors which may also cause manifestation and produce symptoms similar to EPD's have particularly been taken into account:

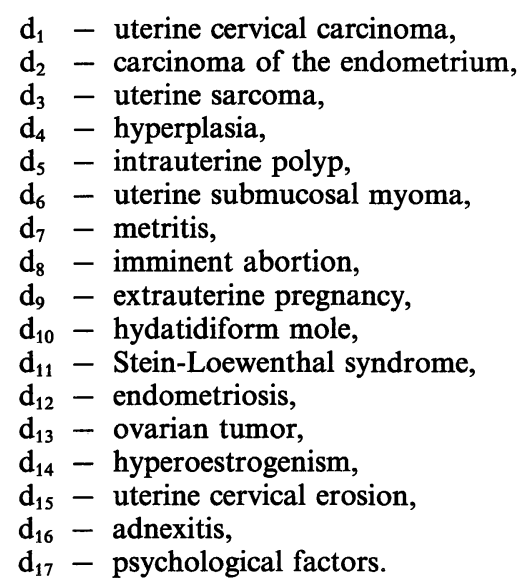

Over eighty symptoms, signs and laboratory findings are assumed to the suitable to be differentiated within the above group of diagnostic possibilities. Forty diagnostic steps were listed for the detection of the manifestations mentioned.

Using the diagnostic problem, the diagnostic hypotheses, the diagnostic tests and their respective results (symptoms, signs and laboratory findings) already defined, an ELSA-method (Experts Lattice Structured Acquirements) has been applied to achieve medical knowledge acquisition and management [2]. Its general principle consists of the total dissection of the diagnostic problem defined in order to ask expert questions that are as simple as possible, and then in the respective composition of the answers obtained to aid the doctor in complex clinical situations. The expert's task has been expressed clearly and exactly in this method by asking him the following questions:

"Which of the two hypotheses $d_{1}, d_{2}$ should be preferred, if a certain manifestation S occurs?"

Answering this question the expert can choose of from the following options: 
- "I do prefer $d_{1}$ rather than $d_{2}$ (or vice versa)",

- "I strongly prefer $d_{1}$ to $d_{2}$ (or vice versa)",

- "The manifestation assumed is of no importance in differentiating between $d_{1}$ and $d_{2}$, or that importance is not known to me".

Such a pattern of expert judgment could be represented by the following sentence:

if $\langle$ diagnostic problem $\rangle$ AND $\left\langle\right.$ manifestation $_{i}$ 〉

Then 〈diagnostic hypothesis $\left.d_{1}\right\rangle \mathrm{R}\langle$ diagnostic hypothesis $\left.d_{2}\right\rangle$

where the relation:

... preferred rather than ...

$R \equiv \ldots$ PREFERRED STRONGLY TO ...

... EQUIVALENT TO ...

reflects the expert's acquirements obtained.

The matrix from figure 1 presents the result of asking the expert on preferences within each pair of diagnostic hypotheses in the light of "no child-

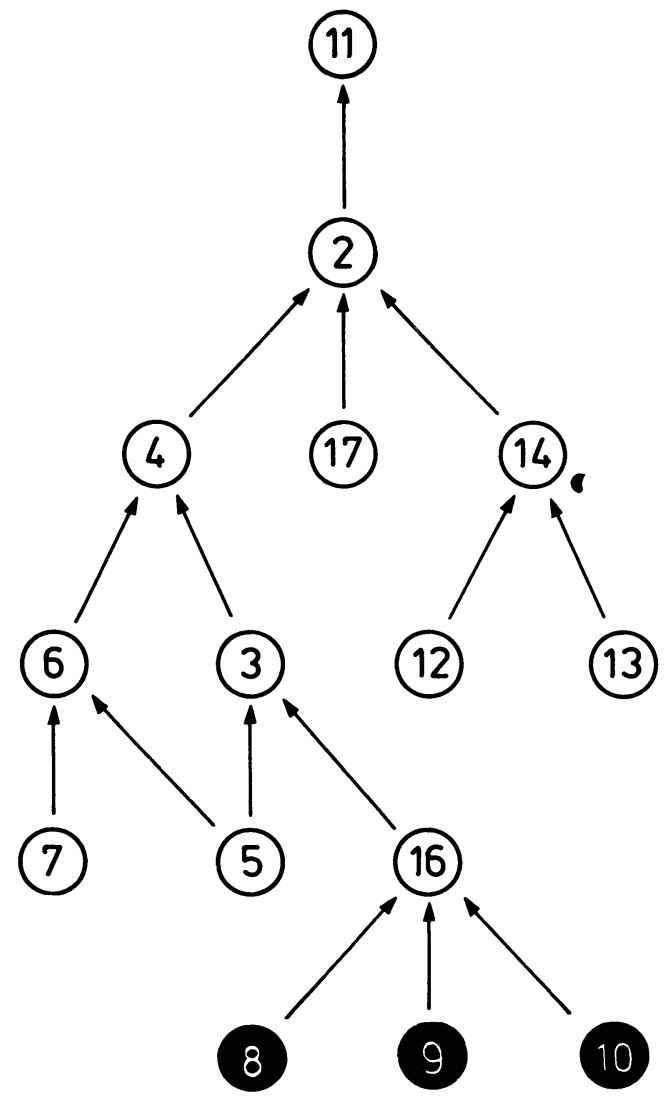

Figure 1. Matrix of order relation including experts' opinions in case of "no childbirth" found in subjective examination. birth" mentioned. The single and double arrows " $", ~ " \rightarrow$ " and " $\Uparrow ", ~ " \Rightarrow "$ in the matrix denote respectively “... PREFERRED RATHER THAN ..." and “... STRONGLY PREFERRED TO ..." relations between diagnostic hypotheses considered. The empty boxes in the matrix denote a lack of preferences, i. e. “... EQUIVALENT TO ...". In figure 2 a graphic representation of the same relation within diagnostic hypotheses can be seen. The black nodes in the graph denote possible diagnoses named as "early pregnancy disorders". It is clearly seen that "no childbirth" stated in the subjective examination markedly prefers hypotheses other than EPDs in the light of the opinion of the experts. When the "patient's age lies between 41 and 60" (figures 3 and 4) the differentiation between EPDs and the group of other hypotheses could not be done so distincty. This data should, therefore, be assumed to be much less relevant for this purpose.

The same assessment can be done with any structure of diagnostic possibilities so arranged, including those obtained as a result of synthesis of symptoms and signs. A special operation has been defined for that procedure [2], according to the rules of the ELSA-method by which the principle of knowledge composition enable medical reasoning to be assisted in any complex clinical situation.

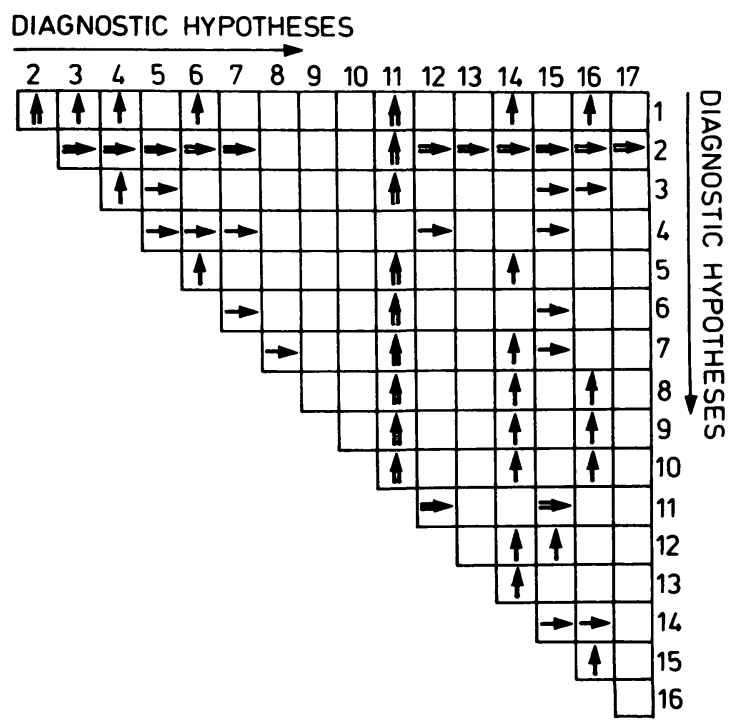

Figure 2. Diagnostic hypotheses ranked according to experts' opinions in case of "no childbirth" when reasons of "irregular vaginal bleeding" are considered. 


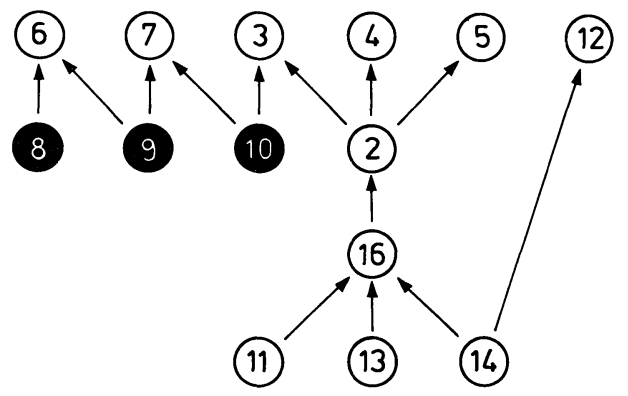

(17)

Figure 3. Matrix of order relation including experts' opinions in case of the "patient's age being between 41 and $60 "$.

\section{DIAGNOSTIC HYPOTHESES}

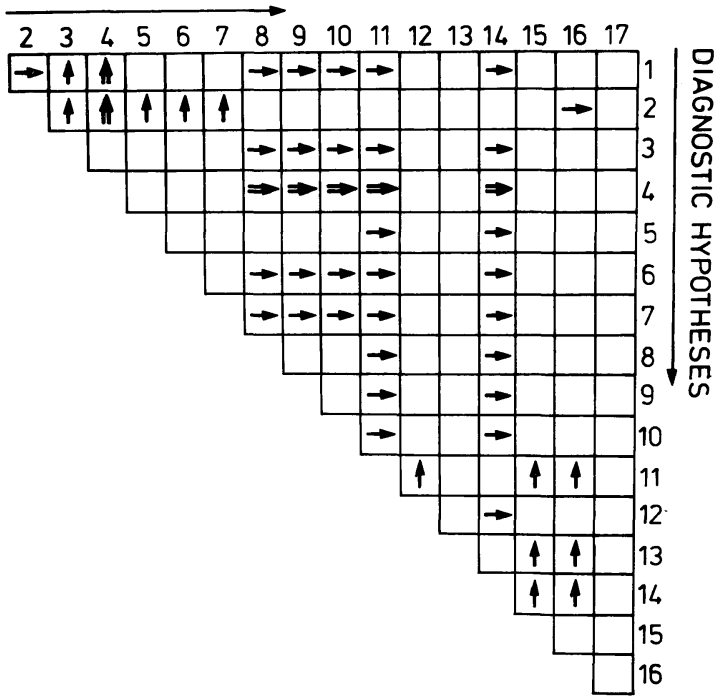

Figure 4. Diagnostic hypotheses ranked according to the experts' opinions in case of "patient's age between 41 and 60 " when reasons of "irregular vaginal bleeding" are being considered.

Let us express now the expert's opinion included in the matrices (figures 1 and 3 ) in terms of the "rules" proposed above. The relation between EPDs and the other possibilities are described only:

a. in case of "no childbirth":

if 'irregular vaginal' bleeding" AND' "no childbirth"

then ("adnexitis" OR "hyperoestrogenism" OR "metritis")

PREFERRED RATHER THAN "EPDs",

"Stein-Loewenthal syndrome" STRONGLY PREFERRED TO "EPDs"; if "irregular vaginal bleeding" AND "no childbirth"

then "EPDs" EQUIVALENT To "any hypothesis other than EPDs";

b. in case of "patient's age between 41 and 60":

if "irregular vaginal bleeding" AND "patient's age between 41 and 60 "

then ("uterine sarcoma" OR "uterine myoma" oR "metritis")

PREFERRED RATHER THAN "EPDs",

"hyperplasia" STRONGLY PREFERRED TO "EPDs",

"EPDs" PREFERRED RATHER THAN ("hyperoestrogenism" OR "Stein-Loewenthal syndrome");

if "irregular vaginal bleeding" AND "patient's age between 41 and 60 "

then "EPDs" EQUIVALENT To "any hypothesis other than EPDs"

To assess the preference of one group of diagnostic hypotheses to another, a special measure $\left(Q^{R}\right)$ has been defined. This is based upon evaluation of the extent to which "blacks" and "whites" are separated within the structure of the diagnostic hypotheses arranged according to the principles of the ELSA-method [3]. In our case the "blacks" represent EPDs in the graphs in figures 2 and 4. as was already mentioned. The measure $Q^{\mathrm{R}}$ allows the assessment either of how far EPDs dominate over the group of other possible diagnoses or how far EPDs are dominated by them in the light of a single manifestation (figures 2 and 4 ) or of any syndrome defined $[3,4]$.

The diagnostic significance of a given symptom, sign or laboratory finding in differentiating between two groups of diagnostic hypotheses could be relatively assessed in this way. When comparing two manifestations (by comparing their respective graphs of "blacks"-and-"whites") the "blacks" and "whites" are better separated in one of them (what is assessed upon respective $Q^{R}$ values), we assume that this manifestation is more significant. Furthermore, the procedure of such relative evaluation of the pairs of symptoms, signs and laboratory findings has potential as a basis of a method for arranging diagnostic steps (tests) according to their expected diagnostic significance [5].

\section{Consultation course: user-system dialogue}

A base of medical knowledge which includes about twelve thousand expert answers has been acquired and used for this work. Figure 5 presents the best 


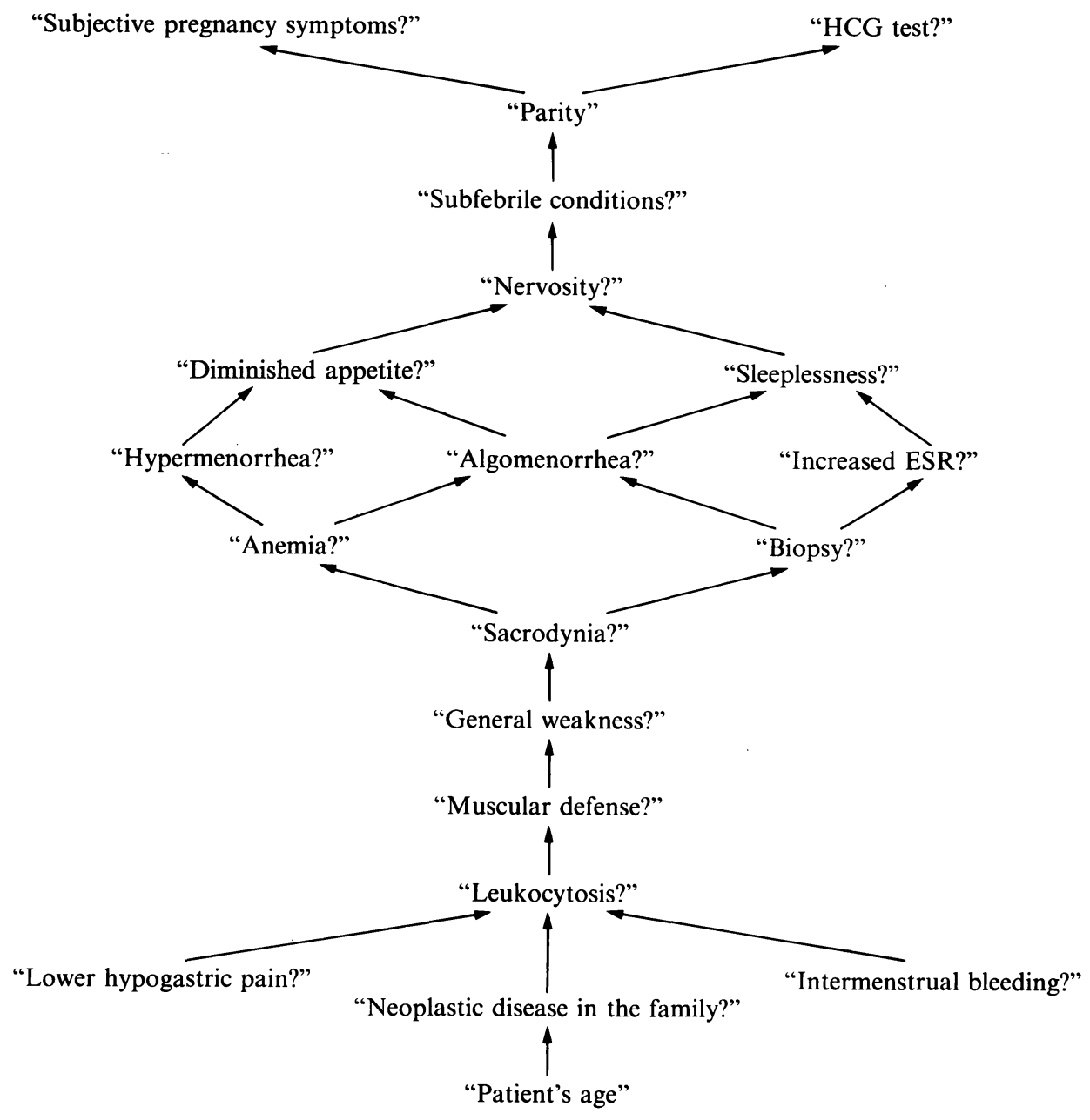

Figure 5. The order of diagnostic steps arranged according to their expected significance to differentiate between "early pregnancy disorders" and other hypotheses considered.

21 diagnostic tests (from the 40 considered) which have been arranged according to their diagnostic significance in order to differentiate between two groups of diagnostic hypotheses: EPDs and all other hypotheses listed previously except "uterine cervical carcinoma" and "uterine cervical erosion", both of which could be easy excluded during the objective examination as causes of irregular vaginal bleeding or lower hypogastric pain. The order of the diagnostic tests set up this way, strongly depends on the contents of both groups of hypotheses to be differentiated. Formation of the working hypotheses is the first step which must be done by the user in order to start the consultation. The system's response in suggesting those diagnostic tests which are the most significant in differentiating within the groups of diagnostic possibilities selected, should aid further steps in planning. The following simple case consultation should make the reader more familiar with the proposed system:

DIAGNOSTIC PROBLEM:

patient referred because of irregular vaginal bleeding. 
USER: initial patient's data acquired:

- occurrence of lower hypogastric pain,

- general weakness observed,

- no neoplastic disease in the family,

- aged $41-60$,

- good social conditions,

- one childbirth,

- secondary amenorrhea,

- hypermenorrhea,

- occurrence of algomenorrhea,

- subjective symptoms of pregnancy,

- normal weight,

- anaemia recognized,

- increased oestrogenic activity.

USER: working hypotheses selected:

EPDs and other hypotheses except

$d_{1}$ - "uterine cervical carcinoma" and

$d_{15}$ - "uterine cervical erosion"

SYSTEM: order of diagnostic hypotheses suggested:

Level 1: $d_{6}, d_{8}, d_{9}$

Level 2: $d_{2}, d_{3}, d_{4}, d_{7}, d_{10}, d_{12}, d_{14}, d_{16}, d_{17}$

Level 3: $d_{13}$,

Level 4: $d_{11}$,

Level 5: $\mathrm{d}_{5}$

COMMENT: EPDs and "uterine myoma" most preferred at this step.

SYSTEM: order of diagnostic steps you are suggested to carry out next:

Level 1: "sacrodynia?"; "subfebrile conditions?"; "diminished appetite?",

Level 2: "nervousness?",

Level 3: "sleeplessness?",

Level 4: "digestive tract disorders?"; "lower limb edema?"; "erythrocyte sedimentation rate"

(only four top levels listed)

USER: next findings acquired:

- "occurrence of sacrodynia",

- "subfebrile conditions observed",

- "diminished appetite",

- "nervousness observed",

- "sleeplessness mentioned",

- "digestive tract disorders observed",

- "rectal tenesmus mentioned",

- "ischialgia observed",

- "no leukocytosis",

- "Muscular defense occurrence"

USER: working hypotheses selected:

As already selected before.
SYSTEM: order of diagnostic hypotheses suggested:

Level 1: $d_{8}$ - "imminent abortion"

Level 2: $d_{9}$ - "ectopic pregnancy"

Level 3: $d_{16}$ - "adnexitis",

Level 4: $d_{6}$ - "uterine myoma"

Level 5: $d_{17}$ - "psychological factors"

Level 6: $d_{7}$ - "metritis"

Level 7: $d_{3}$ - "uterine sarcoma"

Level 8: $d_{14}$ - "hyperoestrogenism"

Level 9: $d_{10}$ - "hydatidiform mole"

Level 10: $d_{12}$ - "endometriosis"

Level 11: $d_{2}-$ "carcinoma of the endometrium"

Level 12: $d_{4}$ - "hyperplasia"

Level 13: $d_{13}$ - "ovarian tumor"

Level 14: $d_{11}$ - "Stein-Loewenthal syndrome"

Level 15: $d_{5}$ - "intrauterine polyp"

The consultation system as well as the expert knowledge base presented in the paper, have been generated from a system shell MEDIATOR (MEdical Diagnosis Inspiration And Tests ORdering) described in [7]. The system can operate on the basic IBM PC/XT configuration, equipped with 256 $\mathrm{RAM}$ and $360 \mathrm{kB}$ floppy-drive only.

\section{Final remarks and conclusions}

The system outlined in this paper has been used in consultation of several hundred cases. These preliminary results seem to be encouraging and also promising. Even this small experience of the operation of the system has allowed us to make the following inferences:

- The task of the experts in the stage of acquisition of knowledge is determined clearly and exactly enough by the method used,

- The suggestions of the system are easily interpretable,

- The diagnostic significance of the tests for the differentiation of EPDs versus other hypotheses varies considerably in which case they can be used in differentiating between particular early pregnancy disorder and other hypotheses assumed.

The small capacity required, the simplicity of operating the system as well as the type of outcomes, make it suitable also to be used in under- and postgraduate training of medical staff. 


\begin{abstract}
The study presents a part of the knowledge-based consultation system for use in a gynecological primary health service to assist doctors who might not be highly experienced, such as junior gynecologists or general practitioners working in small centers, rural areas, developing countries, etc. Aiding the prompt detection of early pregnancy disorders has been considered to reduce complications in these cases, including the life-threatening ones. Although imminent abortion or ectopic pregnancy is usually assumed, all 17 diagnostic 'hypotheses manifested through similiar symptoms are provided. A special experts' knowledge base including 12000 rules formulated according to the ELSA-method (Experts Lattice Structured Acquirements) principles has been completed for this purpose. The following pattern serves for obtaining experts acquirements:

IF (diagnostic problem) AND (manifestation)

THEN (diagnostic hypothesis A) R (diagnostic hypothesis
\end{abstract}

B) where $\mathbf{R}$ denotes one of the following relations: ... "preferred rather than" ..., ... "preferred strongly to" ..., ... "equivalent to" ...

A special procedure has been developed for processing these experts judgements to aid the medical reasoning in complex situations.

The consultation system offers its assitance in:

- differentiation within any given group of diagnostic hypotheses through setting them in order dependent on the patient's manifestations presented,

- selection of the most efficient diagnostic steps for differentiating within the diagnostic hypotheses assumed.

A consultation in the case of the patient with irregular vaginal bleeding has been included. The system operates on IBM PC/XT, equipped with 256 RAM, $360 \mathrm{kB}$ floppy and a printer.

Keywords: Expert system, gynecology/obstetrics, knowledge acquisition, medical expert knowledge, pregnancy disorders.

\section{Zusammenfassung}

\section{Beschwerden in der Frühschwangerschaft: Beratung auf} der Grundlage von Fachwissen

Dieser Beitrag stellt einen Teil eines Forschungsprojektes über die fachwissenbezogene Konsultation bei gynäkologischen Vorsorgeuntersuchungen vor, welche junge, noch unerfahrene Gynäkologen und praktische Ärzte, die an kleinen Zentren, in ländlichen Gegenden und in unterentwickelten Gebieten arbeiten, in ihrer Arbeit unterstützen soll. Insbesondere wurde eine gezielte Aufdeckung von Frühschwangerschaftsbeschwerden (EPD) mittels eines computergestützten Konsultationssystems vorgeschlagen. Ebenso stand dem Arzt auf diese Weise eine angemessene Unterstützung bei der Vorbeugung akuter Komplikationen der EPD zur Verfügung. Weiterhin bot dieses System Hilfestellungen an bei:

- der Differenzierung der diagnostischen Hypothesen innerhalb der vorgegebenen Gruppe durch Ordnen in Abhängigkeit von klinischen und Laborbefunden - der Selektion der diagnostischen Schritte nach Effizienz hinsichtlich der Differenzierung innerhalb der Arbeitshypothesen.

Der Beratungskursus wurde in zwei Schritten geplant: der erste Schritt zielte auf die Erklärung, inwieweit mit EPDs in dem jeweiligen Fall überhaupt zu rechnen war; in einem zweiten Schritt wurde dem Arzt eine Hilfestellung bei der Differenzierung der vermuteten EPDs gegeben. Die Vorschläge des Systems werden in Form von verknüpften Anweisungen innerhalb der diagnostischen Hypothesen bzw. der diagnostischen Tests vorgestellt.

Dieser Versuch basiert im wesentlichen auf der Annahme der Naturverbundenheit des medizinischen Denkens; lieber vergleicht der Arzt diagnostische Hypothesen oder klinische Faktoren miteinander, als daß er versucht, sie nach einer objektiven Maßskala zu bewerten. Der qualitative Charakter der Mehrzahl der medizinischen Daten läßt diese Art zu denken natürlich erscheinen. Entsprechend diesem Prinzip wurde eine ELSA-Methode (Expertenstrukturiertes Erfassungssystem) zur Erlangung und Praktizierung medizinischen Fachwissens eingesetzt. 17 diagnostische Hypothesen (einschl. EPDs) wurden berücksichtigt, und mehr als 80 Symptome, Anzeichen und Laborbefunde wurden im Laufe des diagnostischen Prozesses als signifikant in Betracht gezogen. Die Basis des medizinischen Fachwissens reultierte aus den Fragen an die Experten, welche Präferenzen diese unter Berücksichtigung jeden Symptoms, Anzeichens oder Laborbefundes innerhalb jeden Paares der diagnostischen $\mathrm{Hy}-$ pothesen setzten. Etwa 12000 solcher Fragen an die Experten waren erforderlich, um für diese Studie eine hinreichende und verständliche Wissensbasis zu erhalten. Das spezielle $M a ß Q^{R}$ wurde vorgeschlagen, um sowohl innerhalb der Hypothesengruppen (EPDs vs. andere Hypothesen) als auch zwischen den relevanten Tests hinsichtlich ihrer diagnostischen Signifikanz für solche Unterscheidungen effizient $\mathrm{zu}$ unterscheiden.

Das System läuft auf einem IBM PC/XT Mikro (oder einem äquivalenten Gerät) mit einer Ausstattung von nur 256 kB RAM und $360 \mathrm{kB}$ Diskettenlaufwerk. Diese Kapazität reicht aus zur Speicherung sowohl des Programms als auch des medizinischen Fachwissens.

Mehrere hundert Fälle sind mit dem beschriebenen System bearbeitet worden (ein ausgewählter Fall einer Konsultation wurde vorgestellt). Die ersten Ergebnisse waren ermutigend und zugleich vielversprechend. Die 
ELSA-Methode hat sich als ausreichend geeignet zum Erwerb und zur Anwendung von medizinischem Fachwissen erwiesen.

Das Systemgerüst MEDIATOR (MEdical Diagnosis Inspiration And Test ORdering) hat sich in seiner Anwen- dung als Erstellungsmodul der hier vorgestellten Konsultationsabläufe als relevantes Werkzeug für weitere Systementwicklung erwiesen, indem es andere wichtige Probleme als Gegenstand der auf Fachwissen basierenden Konsultation mit einschließt.

Schlüsselwörter: Expertensystem, Gynäkologie/Geburtshilfe, medizinisches Fachwissen, Schwangerschaftsbeschwerden, Wissenserwerb.

\section{Résumé}

Pathologie du début de la grossesse: consultation d'une base de connaissance experte

Cet article présente une partie d'un projet de recherche ayant trait à la consultation de bases de connaissances en service de santé primaire pour la gynécologie afin d'aider les médecins peu expérimentés, les jeunes gynécologues ou les médecins généralistes qui travaillent dans de petits centres, en zone rurale, dans des pays en voie de développement, etc... Tout particulièrement un système de consultations aidées par ordinateur a été proposé comme aide à la détection de la pathologie du début de la grossesse (EPD). On peut aussi fournir au médecin par ce moyen une aide raisonable pour éviter les complications concevables aigües de l'EPD.

Le système présenté offre son assistance pour:

- la différenciation au sein des groupes d'hypothèses diagnostiques permettant de les placer dans l'ordre suivant les données cliniques et complémentaires reconnues.

- la sélection des étapes diagnostiques plus efficace dans l'optique d'une différenciation parmi les hypothèses de travail sélectionnées.

On a considéré le déroulement de la consultation comme une procédure en deux phases visant à expliquer pour le cas considéré comment chaque EPD peut être suspectée, puis à donner au médecin une assistance lui permettant de faire la différence au sein des EPD supposées. Les suggestions du système sont proposées sous le forme de relations d'ordre parmi l'ensemble des autres hypothèses diagnostiques ou des tests diagnostiques. Cette approche a été fortement fondée sur l'hypothèse de la nature relationelle du raisonnement médical; le médecin compare les hypothèses diagnostiques ou les faits cliniques l'un à l'autre plus qu'il ne les trie afin de les évaluer à l'aide d'une échelle objective. La note qualitative de la majorité des données médicales rend naturel ce mode de pensée. Selon ce principe, une méthode ELSA (connaissances expertes structurées en réseau) a été uti- lisée pour l'acquisition de connaissances médicales expertes et la prise en charge. Dix sept hypothèses diagnostiques (comprenant les EPD) ont été considérées et plus de quatre vingt symptomes, signes et résultats de laboratoire ont été pris en compte en tant qué ayant une signification dans le déroulement du processus diagnostique. Cette base de connaissance médicale a été élaborée sur les résultats d'interrogations d'experts sur leurs préférences au sein de chaque paire d'hypothèses diagnostique comparées à la lumière de chaque symptome, signe ou résultat de laboratoire considéré. Environ douze mille de ces questions ont été proposées aux experts pour obtenir une base de connaissance médicale fiable et suffisamment compréhensible pour cette étude. On a proposé une mesure $\mathrm{Q}^{\mathrm{R}}$ spéciale afin de différencier efficacement au sein des groupes d'hypothèses (EPD versus les autres hypothèses) aussi bien que de sélectionner les tests les plus appropriée dans l'optique de leurs significations diagnostiques pour une telle différentiation.

Le système fonctionne sur microprocesseur IBM PC/XT (ou équivalent), équipé de $256 \mathrm{~KB}$ RAM et de $360 \mathrm{~KB}$ floppy-drive seulement. Cette capacité suffit pour stocker et le programme et la base de connaissances médicales acquises.

Quelques centaines de cas ont été consultés avec le système décrit (on a assuré un cas particulièr de la consultation). On peut estimer que les résultats initiaux sont encourageants et prometteurs. La méthode ELSA est apparue suffisamment appropriée pour l'acquisition de connaissances expertes et pour la prise en charge.

Le système MEDIATOR utilisé comme un générateur de méthodes de consultation, exposé dans cet article, a fait la preuve qu'il est un outil pertinent pour d'autres développements de systèmes par inclusion d'autres problèmes importants sujets de consultations de bases de connaissances.

Mots-clés: Acquisition de connaissances, connaissance médicale experte, gynécologie/obstétrique, pathologie de la grossesse, système expert. 


\section{References}

[1] KuImek R: Gynecology, Polish Medical Publishing House, Warsaw 1981

[2] Ruszkowski J: ELSA - A Method for Medical Knowledge Acquisition and Processing to Aid Medical Reasoning, Methods Inform Med 25 (1986) 79

[3] RuszKowski J: Expert Knowledge-Based System to Aid an Early Detection of Uterus Body Neoplastic Changes. In: SerIo A. et al: Proceedings of Medical Informatics Europe '87, Rome, EDI Press, Rome 1987

[4] Ruszkowski J: Computer-Aided Consultation Based upon Medical Experts Knowledge in Gynecologic Primary Health Service. In: Carson, E (eds): Advances in Biomedical Measurement, Plenum Press, London-New York 1988

[5] Ruszkowski J: Clinical Significance of Symptoms and Signs Assessed upon Medical Experts Knowledge, Application to the Common Diagnostic Problems in Gynecology. Wissenschaftliche Zeitschrift der TH Ilmenau, 34 (1988) 95

[6] Ruszkowski J: Vaginal Bleeding in Early Pregnancy: Computer-Aided Consultation Based on Medical Expert Knowledge. J Perinat Med [Suppl] 15 (1987) 16
[7] Ruszkowski J: Computer-Aided Medical Consultation Based on Experts Knowledge Structures. In: VAN Bemmel, JH (eds) - Medical Decision Making: Diagnostic Stragegies and Expert Systems, Elsevier Science Publishers B.V. (North Holland), Amsterdam 1985

[8] RUSZKowski J, B SKarzyŃSKI, W WiśNIEWSKa: Knowledge-based System for Aiding an Explanation of Commonly Met Symptoms in Ambulatory Gynecology. J Perinat Med [Suppl] 15 (1987) 41

[9] Shortliffe EH: Computer-based Medical Consultations: MYCIN. American Elsevier, New York 1976

[10] Wolfe HM, BC DeCKer, RJ SoKol: ComputerAided Instruction for OB-GYN: A Prototype Programmed Practical Patient Care Protocol. J. Perinat Med [Suppl] 15 (1987) 257

Dr. Jacek Ruszkowski

Medical Center of Postgraduate Education 99, Marymoncka Street, PL-01-813 Warszawa, Poland 


\section{Concise Encyclopedia Biochemistry}

Second Edition, revised and expanded by Thomas Scott and Mary Eagleson 1988. $17 \mathrm{~cm} \times 24 \mathrm{~cm} .650$ pages. Hardcover. DM 148,-; approx. US $\$ 89.00$ ISBN 3110116251

The only single work of its kind in English, the Concise Encyclopedia of Biochemistry provides a comprehensive, yet compact, source of biochemical data and information for the researcher, teacher, and student.

Special features of this edition include:

- Approximately 4,500 entries

- Up-to-date, comprehensive

- Coverage of medical, animal, microbial, plant, and physical biochemistry, natural products, molecular biology, molecular genetics, and biotechnology

- Hundreds of illustrations, including structural formulas, schemes, and metabolic pathways

- Over 100 tables

- Modern terminology based on standard sources, e. g., IUB Enzyme Nomenclature

- Standard biochemical abbreviations

- Extensive cross references with synonyms provided

- Literature references are cited to aid the reader in locating original sources

Potential audience: biochemists, clinical biochemists, clinical chemists, medical researchers, clinicians, plant scientists, experimental biologists, lecturers and students of the life sciences.

Price is subject to change without notice

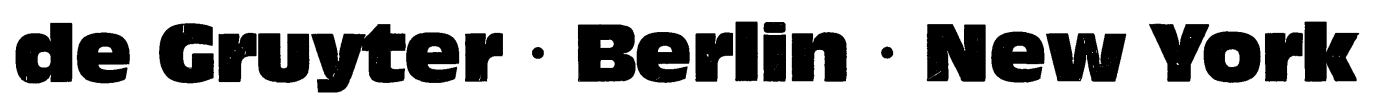

